\title{
Briarane Diterpenoids from the Formosan Gorgonian Coral Junceella fragilis
}

\author{
Ping-Jyun Sung, * Mei-Ru Lin, and Lee-Shing FAnG \\ National Museum of Marine Biology and Aquarium; 2 Houwan Road, Checheng, Pingtung 944, Taiwan, R.O.C. \\ Received July 28, 2004; accepted September 3, 2004
}

\begin{abstract}
A new trihydroxy briarane-related diterpenoid, junceellolide I (1), along with a known metabolite, $(1 R, 2 R, 5 Z, 7 R, 8 S, 9 R, 10 R, 12 R, 14 R, 17 S)$-2,14-diacetoxy-8,17-epoxy-9,12-dihydroxybriara-5,11(20)-dien-19-one (2), have been isolated from the gorgonian coral Junceella fragilis, collected off the southern Taiwan coast. The structure, including the relative configuration of the new compound 1, was elucidated by the combination of spectral data, particularly in high-resolution ${ }^{1} \mathrm{H}$ - and ${ }^{13} \mathrm{C}$-NMR spectroscopy utilizing COSY, HMBC, HMQC, and NOESY experiments.
\end{abstract}

Key words Junceella fragilis; junceellolide; gorgonian; briarane

Previous chemical investigations of the gorgonian coral Junceella fragilis (phylum Cnidaria, class Anthozoa, subclass Octocorallia, order Gorgonacea, family Ellisellidae $)^{1-3)}$ have yielded 15 new diterpenoids possessing the briarane skeleton. These metabolites are junceellolides $\mathrm{A}-\mathrm{H},{ }^{4-6)}(-)-4-$ deacetyljunceellolide $\mathrm{D}, \quad(+)-11 \alpha, 20 \alpha$-epoxyjunceellolide $\mathrm{D},(-)-11 \alpha, 20 \alpha$-epoxy-4-deacetyljunceellolide $\mathrm{D},(-)-11 \alpha$, $20 \alpha$-epoxy-4-deacetoxyjunceellolide $\mathrm{D}, \quad(+)$-junceellolide $\mathrm{A},{ }^{7}$ 9-O-deacetylumbraculolide $\mathrm{A},{ }^{8)}$ and fragilide $\mathrm{A} .{ }^{9)}$ In addition to species of the genus Junceella ${ }^{10)}$ briarane-type metabolites have also been isolated from a variety of marine organisms, and the compounds of this type were found to possess extensive biological activity, ${ }^{11)}$ and could be originally synthesized by the corals. ${ }^{12,13)}$ In this paper, we report the isolation and structure determination of two briarane derivatives, including a new briarane, junceellolide I (1), together with a known metabolite, $(1 R, 2 R, 5 Z, 7 R, 8 S, 9 R, 10 R$, $12 R, 14 R, 17 S)$-2,14-diacetoxy-8,17-epoxy-9,12-dihydroxybriara-5,11(20)-dien-19-one (2), ${ }^{14)}$ from the gorgonian coral Junceella fragilis collected off southern Taiwan coast. The structure of the new diterpenoid 1 was elucidated by combined analysis of spectral data.

Junceellolide I (1) was obtained as white powder, $[\alpha]_{\mathrm{D}}^{25}$ $-77^{\circ}\left(c=0.7, \mathrm{CHCl}_{3}\right)$. This metabolite has a molecular formula of $\mathrm{C}_{24} \mathrm{H}_{36} \mathrm{O}_{9}$ as established by FAB-MS and NMR data, which indicates seven degrees of unsaturation. The IR absorptions of 1 showed the presence of hydroxy $\left(3352 \mathrm{~cm}^{-1}\right)$, $\gamma$-lactone $\left(1775 \mathrm{~cm}^{-1}\right)$, and ester $\left(1736 \mathrm{~cm}^{-1}\right)$ groups. The FAB-MS of 1 exhibited peaks at $m / z 451\left(\mathrm{M}+\mathrm{H}-\mathrm{H}_{2} \mathrm{O}\right)^{+}$, $433\left(\mathrm{M}+\mathrm{H}-2 \mathrm{H}_{2} \mathrm{O}\right)^{+}, 391\left(\mathrm{M}+\mathrm{H}-\mathrm{AcOH}-\mathrm{H}_{2} \mathrm{O}\right)^{+}, 373(\mathrm{M}+$ $\left.\mathrm{H}-\mathrm{AcOH}-2 \mathrm{H}_{2} \mathrm{O}\right)^{+}, 349(\mathrm{M}+\mathrm{H}-2 \mathrm{AcOH})^{+}, 331(\mathrm{M}+\mathrm{H}-$ $\left.2 \mathrm{AcOH}-\mathrm{H}_{2} \mathrm{O}\right)^{+}, 313\left(\mathrm{M}+\mathrm{H}-2 \mathrm{AcOH}-2 \mathrm{H}_{2} \mathrm{O}\right)^{+}$, and 295 $\left(\mathrm{M}+\mathrm{H}-2 \mathrm{AcOH}-3 \mathrm{H}_{2} \mathrm{O}\right)^{+}$, also indicating the presence of two acetoxy and three hydroxy groups in 1 . From the ${ }^{13} \mathrm{C}$ NMR data of 1 (Table 1), the presence of a trisubstituted olefin was deduced from the signals of two carbons resonating at $\delta_{\mathrm{C}} 146.2$ (s) and 119.0 (d). Furthermore, in the ${ }^{13} \mathrm{C}$ NMR spectrum, three carbonyl resonances appeared at $\delta_{\mathrm{C}}$ $176.2(\mathrm{~s}), 170.3(\mathrm{~s})$, and $169.4(\mathrm{~s})$, confirming the presence of a $\gamma$-lactone and two esters in 1 . In the ${ }^{1} \mathrm{H}$-NMR spectrum of 1 (Table 1), two acetyl methyl groups $\left(\delta_{\mathrm{H}} 2.18,3 \mathrm{H}, \mathrm{s} ; 2.06\right.$, $3 \mathrm{H}, \mathrm{s})$ were observed. Thus, the NMR data accounted for four degrees of unsaturation and requiring 1 to be tricyclic.
The ${ }^{1} \mathrm{H}-\mathrm{NMR}$ spectrum also showed the presence of four methyl groups, including a methyl $\left(\delta_{\mathrm{H}} 1.16,3 \mathrm{H}, \mathrm{d}\right.$, $\left.J=7.5 \mathrm{~Hz}, \mathrm{H}_{3}-18\right)$ attached to a methine carbon, a methyl $\left(\delta_{\mathrm{H}}\right.$ $\left.0.97,3 \mathrm{H}, \mathrm{s}, \mathrm{H}_{3}-15\right)$ attached to a tertiary carbon, a methyl $\left(\delta_{\mathrm{H}} 1.43,3 \mathrm{H}, \mathrm{s}, \mathrm{H}_{3}-20\right)$ attached to an oxygen-bearing quaternary carbon, and a vinyl methyl $\left(\delta_{\mathrm{H}} 2.03,3 \mathrm{H}, \mathrm{s}, \mathrm{H}_{3}-16\right)$.

The gross structure of 1 and all of the ${ }^{1} \mathrm{H}-$ and ${ }^{13} \mathrm{C}-\mathrm{NMR}$ data associated with the molecule were determined by $2 \mathrm{D}$ NMR studies, including ${ }^{1} \mathrm{H}-{ }^{1} \mathrm{H}$ correlation spectroscopy (COSY), ${ }^{1} \mathrm{H}$-detected heteronuclear multiple quantum coherence (HMQC), and heteronuclear multiple bond connectivity (HMBC) experiments. From the ${ }^{1} \mathrm{H}-{ }^{1} \mathrm{H}$ COSY spectrum of 1 (Fig. 1), it was possible to establish the separate spin systems that map out the proton sequences from $\mathrm{H}-2 / \mathrm{H}_{2}-3 ; \mathrm{H}_{2}-3 / \mathrm{H}_{2}-$ 4; $\mathrm{H}-6 / \mathrm{H}-7$; and $\mathrm{H}-9 / \mathrm{H}-10$. These data, together with the HMBC correlations between $\mathrm{H}-2 / \mathrm{C}-1, \mathrm{C}-3, \mathrm{C}-4, \mathrm{C}-10 ; \mathrm{H}_{2}-$ 3/C-1, C-2, C-4, C-5; H $2-4 / \mathrm{C}-3$, C-5, C-6; H-7/C-5, C-6, C-8; $\mathrm{H}-9 / \mathrm{C}-7, \mathrm{C}-8, \mathrm{C}-10$; and $\mathrm{H}-10 / \mathrm{C}-1, \mathrm{C}-2$, C-8, C-9 (Fig. 1, Table 1), established the connectivity from $\mathrm{C}-1$ to $\mathrm{C}-10$ within the ten-membered ring. A vinyl methyl attached at $\mathrm{C}$ 5 was confirmed by the long-range ${ }^{1} \mathrm{H}-{ }^{1} \mathrm{H}$ COSY correlations between $\mathrm{H}_{3}-16$ and $\mathrm{H}-6$ and the $\mathrm{HMBC}$ correlations between $\mathrm{H}_{3}-16 / \mathrm{C}-4, \mathrm{C}-5$, and C- 6 . The methylcyclohexane ring was elucidated by the combination of ${ }^{1} \mathrm{H}-{ }^{1} \mathrm{H}$ COSY correlations between $\mathrm{H}_{2}-12 / \mathrm{H}_{2}-13$ and $\mathrm{H}_{2}-13 / \mathrm{H}-14$ and the HMBC correlations between $\mathrm{H}_{2}-12 / \mathrm{C}-11, \mathrm{C}-20 ; \mathrm{H}_{2}-13 / \mathrm{C}-1$, $\mathrm{C}-11, \mathrm{C}-12$, C-14; H-14/C-10, C-12, C-13; and $\mathrm{H}_{3}-20 / \mathrm{C}-10$, $\mathrm{C}-11, \mathrm{C}-12$. The methylcyclohexane ring, which is fused to the ten-membered ring at $\mathrm{C}-1$ and $\mathrm{C}-10$, was elucidated by the long-range $W$-coupling between $\mathrm{H}-10$ and $\mathrm{H}-12 \alpha$ and by the key HMBC correlations between $\mathrm{H}-2 / \mathrm{C}-14$; H-9/C-11; $\mathrm{H}-10 / \mathrm{C}-11$; and $\mathrm{H}-14 / \mathrm{C}-2$. The ring-juncture $\mathrm{C}-15$ methyl group was positioned at $\mathrm{C}-1$ from the key $\mathrm{HMBC}$ correlations between $\mathrm{H}_{3}-15 / \mathrm{C}-1, \mathrm{C}-2, \mathrm{C}-10, \mathrm{C}-14$. Furthermore, the acetoxy groups positioned at $\mathrm{C}-2$ and $\mathrm{C}-9$ were confirmed from the HMBC correlations between $\delta_{\mathrm{H}} 4.51(\mathrm{H}-2), 5.18$ $(\mathrm{H}-9)$ and the ester carbonyl carbons appeared at $\delta_{\mathrm{C}} 170.3$ (s), 169.4 (s), respectively. In addition, the proton of the hydroxy-bearing methine showed the signal at $\delta_{\mathrm{H}} 4.12(1 \mathrm{H}, \mathrm{d}$, $J=5.0 \mathrm{~Hz}$ ) was assigned to $\mathrm{H}-14$. The 11-hydroxy group was confirmed from the signal of a quaternary oxygen-bearing carbon at $\delta_{\mathrm{C}} 89.1$ (s) and from the chemical shift of the tertiary methyl $\mathrm{H}_{3}-20\left(\delta_{\mathrm{H}} 1.43,3 \mathrm{H}, \mathrm{s}\right)$. Thus, the remaining 
Table 1. ${ }^{1} \mathrm{H}$ - and ${ }^{13} \mathrm{C}$-NMR Chemical Shifts and HMBC and ${ }^{1} \mathrm{H}-{ }^{1} \mathrm{H}$ COSY Correlations for $\mathbf{1}$

\begin{tabular}{|c|c|c|c|c|}
\hline $\mathrm{C} / \mathrm{H}$ & ${ }^{1} \mathrm{H}^{a)}$ & ${ }^{13} C^{b)}$ & $\operatorname{HMBC}(\mathrm{H} \rightarrow \mathrm{C})$ & ${ }^{1} \mathrm{H}-{ }^{1} \mathrm{H} \mathrm{COSY}$ \\
\hline 1 & & $51.6(\mathrm{~s})^{d)}$ & $\mathrm{H}-2, \mathrm{H}_{2}-3, \mathrm{H}-10, \mathrm{H}_{2}-13, \mathrm{H}_{3}-15$ & \\
\hline 2 & $\left.4.51(1 \mathrm{H}, \mathrm{t}, J=5.0 \mathrm{~Hz})^{c}\right)$ & $77.4(\mathrm{~d})$ & $\mathrm{H}_{2}-3, \mathrm{H}-4 \alpha, \mathrm{H}-10, \mathrm{H}-14, \mathrm{H}_{3}-15$ & $\mathrm{H}-3 \alpha / \beta$ \\
\hline $3 \alpha$ & $1.91 \mathrm{~m}$ & $32.6(\mathrm{t})$ & $\mathrm{H}-2, \mathrm{H}_{2}-4$ & $\mathrm{H}-2, \mathrm{H}-3 \beta, \mathrm{H}-4 \alpha / \beta$ \\
\hline$\beta$ & $2.04 \mathrm{~m}$ & & & $\mathrm{H}-2, \mathrm{H}-3 \alpha, \mathrm{H}-4 \alpha / \beta$ \\
\hline $4 \alpha$ & $2.29(1 \mathrm{H}, \mathrm{ddd}, J=15.0,10.5,5.0 \mathrm{~Hz})$ & $28.9(\mathrm{t})$ & $\mathrm{H}-2, \mathrm{H}_{2}-3, \mathrm{H}_{3}-16$ & $\mathrm{H}-3 \alpha / \beta ; \mathrm{H}-4 \beta$ \\
\hline$\beta$ & $2.59(1 \mathrm{H}, \mathrm{dt}, J=15.0,5.0 \mathrm{~Hz})$ & & & $\mathrm{H}-3 \alpha / \beta ; \mathrm{H}-4 \alpha$ \\
\hline 5 & & $146.2(\mathrm{~s})$ & $\mathrm{H}_{2}-3, \mathrm{H}_{2}-4, \mathrm{H}-7, \mathrm{H}_{3}-16$ & \\
\hline 6 & $5.46(1 \mathrm{H}, \mathrm{d}, J=9.5 \mathrm{~Hz})$ & $119.0(\mathrm{~d})$ & $\mathrm{H}_{2}-4, \mathrm{H}-7, \mathrm{H}_{3}-16$ & $\mathrm{H}-7, \mathrm{H}_{3}-16$ \\
\hline 7 & $5.27(1 \mathrm{H}, \mathrm{d}, J=9.5 \mathrm{~Hz})$ & $77.6(d)$ & $\mathrm{H}-9, \mathrm{OH}-8$ & H-6 \\
\hline 8 & & $80.9(\mathrm{~s})$ & H-7, H-9, H-10, H-17, $\mathrm{H}_{3}-18, \mathrm{OH}-8$ & \\
\hline 9 & $5.18(1 \mathrm{H}, \mathrm{d}, J=6.0 \mathrm{~Hz})$ & $68.3(\mathrm{~d})$ & H-10, H-17, OH-8 & $\mathrm{H}-10$ \\
\hline 10 & $2.13(1 \mathrm{H}, \mathrm{dd}, J=6.0,2.0 \mathrm{~Hz})$ & $49.9(\mathrm{~d})$ & $\mathrm{H}-2, \mathrm{H}-9, \mathrm{H}_{2}-12, \mathrm{H}-14, \mathrm{H}_{3}-15, \mathrm{H}_{3}-20$ & H-9, $\mathrm{H}-12 \alpha$ \\
\hline 11 & & $89.1(\mathrm{~s})$ & $\mathrm{H}-9, \mathrm{H}-10, \mathrm{H}_{2}-12, \mathrm{H}_{2}-13, \mathrm{H}_{3}-20$ & \\
\hline $12 \alpha$ & $1.30(1 \mathrm{H}, \mathrm{m})$ & $29.2(\mathrm{t})$ & $\mathrm{H}-10, \mathrm{H}_{2}-13, \mathrm{H}-14, \mathrm{H}_{3}-20$ & $\mathrm{H}-10, \mathrm{H}-12 \beta, \mathrm{H}-13 \alpha / \beta$ \\
\hline$\beta$ & $2.00(1 \mathrm{H}, \mathrm{m})$ & & & $\mathrm{H}-12 \alpha, \mathrm{H}-13 \alpha / \beta$ \\
\hline $13 \alpha$ & $2.88(1 \mathrm{H}, \mathrm{m})$ & $27.9(\mathrm{t})$ & $\mathrm{H}-14$ & $\mathrm{H}-12 \alpha / \beta, \mathrm{H}-13 \beta, \mathrm{H}-14$ \\
\hline$\beta$ & $1.68(1 \mathrm{H}, \mathrm{m})$ & & & $\mathrm{H}-12 \alpha / \beta, \mathrm{H}-13 \alpha, \mathrm{H}-14$ \\
\hline 14 & $4.12(1 \mathrm{H}, \mathrm{d}, J=5.0 \mathrm{~Hz})$ & $82.1(\mathrm{~d})$ & $\mathrm{H}-2, \mathrm{H}_{2}-13, \mathrm{H}_{3}-15$ & $\mathrm{H}-13 \alpha / \beta$ \\
\hline 15 & $0.97(3 \mathrm{H}, \mathrm{s})$ & $15.4(\mathrm{q})$ & $\mathrm{H}-2, \mathrm{H}-10$ & \\
\hline 16 & $2.03(3 \mathrm{H}, \mathrm{s})$ & $26.5(\mathrm{q})$ & $\mathrm{H}-4 \alpha, \mathrm{H}-6$ & H-6 \\
\hline 17 & $2.43(1 \mathrm{H}, \mathrm{q}, J=7.5 \mathrm{~Hz})$ & $42.0(\mathrm{~d})$ & $\mathrm{H}-9, \mathrm{H}_{3}-18, \mathrm{OH}-8$ & $\mathrm{H}_{3}-18$ \\
\hline 18 & $1.16(3 \mathrm{H}, \mathrm{d}, J=7.5 \mathrm{~Hz})$ & $6.6(q)$ & $\mathrm{H}-17$ & $\mathrm{H}-17$ \\
\hline 19 & & $176.2(\mathrm{~s})$ & $\mathrm{H}-17, \mathrm{H}_{3}-18$ & \\
\hline 20 & $1.43(3 \mathrm{H}, \mathrm{s})$ & $23.2(q)$ & $\mathrm{H}-10, \mathrm{H}_{2}-12$ & \\
\hline $\mathrm{OH}-8$ & $1.97(1 \mathrm{H}, \mathrm{s})$ & & & \\
\hline \multirow[t]{4}{*}{ Acetates } & $2.18(3 \mathrm{H}, \mathrm{s})$ & $21.4(q)$ & & \\
\hline & & $169.4(\mathrm{~s})$ & H-9, acetate methyl & \\
\hline & $2.06(3 \mathrm{H}, \mathrm{s})$ & $21.1(\mathrm{q})$ & & \\
\hline & & $170.3(\mathrm{~s})$ & $\mathrm{H}-2$, acetate methyl & \\
\hline
\end{tabular}

a) Measured at $500 \mathrm{MHz}$ in $\mathrm{CDCl}_{3}$ at $25^{\circ} \mathrm{C}$. b) Measured at $125 \mathrm{MHz}$ in $\mathrm{CDCl}_{3}$ at $\left.25^{\circ} \mathrm{C} . \quad c\right) J$ values (in $\mathrm{Hz}$ ) in parentheses. d) Multiplicity deduced by DEPT and in dicated by usual symbols.

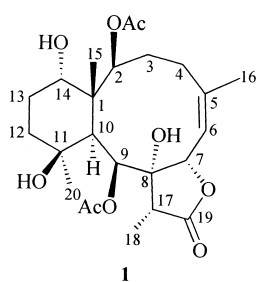

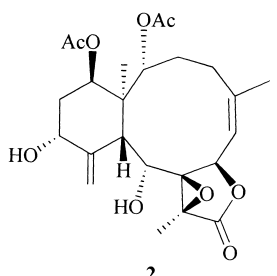

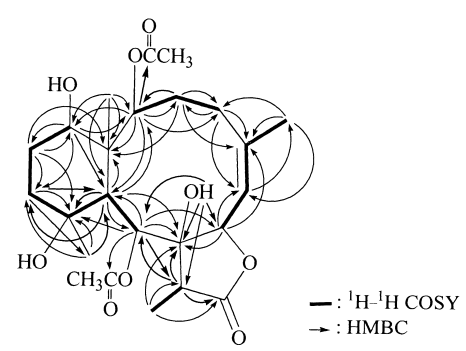

Fig. 1. The ${ }^{1} \mathrm{H}-{ }^{1} \mathrm{H}$ COSY and HMBC Correlations of $\mathbf{1}$

hydroxy group had to be positioned at C-8, an oxygen-bearing quaternary carbon resonating at $\delta_{\mathrm{C}} 80.9$. The latter was further confirmed from the HMBC correlations observed between $\mathrm{OH}-8 / \mathrm{C}-7$, C-8, C-9, C-17. These data, together with the HMBC correlations between $\mathrm{H}_{3}-18 / \mathrm{C}-8, \mathrm{C}-17$, $\mathrm{C}-19$, unambiguously established the molecular framework of 1 .

The relative stereochemistry of $\mathbf{1}$ was elucidated from the NOE interactions observed in a nuclear overhauser effect spectroscopy (NOESY) experiment (Fig. 2). In the NOESY experiment of 1, $\mathrm{H}-10$ gives NOE correlations to $\mathrm{H}-2, \mathrm{OH}-8$,

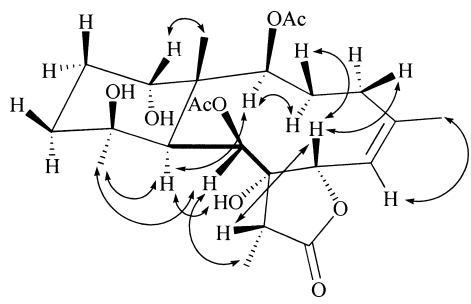

Fig. 2. Selective NOE Correlations of $\mathbf{1}$

and $\mathrm{H}_{3}-20$, but not to $\mathrm{H}_{3}-15$, and $\mathrm{H}-2$ was found to show NOE responses with one proton of the C-3 methylene $\left(\delta_{\mathrm{H}} 1.91, \mathrm{~m}, \mathrm{H}-3 \alpha\right)$, indicating that these protons are located on the same face of the molecule and assigned as $\alpha$-protons, since C-15 methyl and 11-hydroxy groups are the $\beta$-substituents at C-1 and C-11, respectively, and 8-hydroxy group was $\alpha$-oriented. H-14 was found to exhibit NOE responses with $\mathrm{H}_{3}-15$, but not with $\mathrm{H}-10$, revealing the $\beta$-orientation of this proton. Furthermore, $\mathrm{H}-7$ was found to exhibit NOE correlations with $\mathrm{H}-3 \beta$, one proton of the $\mathrm{C}-4$ methylene $\left(\delta_{\mathrm{H}} 2.59,1 \mathrm{H}, \mathrm{dt}, J=15.0,5.0 \mathrm{~Hz}, \mathrm{H}-4 \beta\right)$, and $\mathrm{H}-17$, but not with $\mathrm{OH}-8$, indicating $\mathrm{H}-7$ and $\mathrm{H}-17$ should be placed on the $\beta$ face and $\mathrm{H}_{3}-18$ was $\alpha$-oriented in 1 . H-9 was found to show NOE responses with $\mathrm{H}_{3}-18$ and $\mathrm{H}_{3}-20$. From the consideration of molecular models, H-9 was found to be reasonably close to $\mathrm{H}_{3}-18$ and $\mathrm{H}_{3}-20$, thus being concluded that $\mathrm{H}-9$ should be placed on the $\alpha$ face in 1 . From the above results, the structure, including the relative configuration of $\mathbf{1}$, was established unambiguously.

Compound $\mathbf{2}$ was identified as a known diterpene, 
$(1 R, 2 R, 5 Z, 7 R, 8 S, 9 R, 10 R, 12 R, 14 R, 17 S)$-2,14-diacetoxy8,17-epoxy-9,12-dihydroxybriara-5,11(20)-dien-19-one, which had been isolated from an Australian gorgonian coral Junceella gemmacea. Its physical (optical rotation value) and spectral $\left({ }^{1} \mathrm{H}-\right.$ and $\left.{ }^{13} \mathrm{C}-\mathrm{NMR}\right)$ data are in full agreement with those reported previously. ${ }^{14)}$

\section{Experimental}

Melting points were determined using a FARGO apparatus and were uncorrected. Optical rotation values were measured in $\mathrm{CHCl}_{3}$ using a JASCO D-370 digital polarimeter at $25^{\circ} \mathrm{C}$. Infrared spectra were recorded on a JASCO 5300 FT-IR. FAB-MS was obtained with a VG QUATTRO GC/MS spectrometer. HR-FAB-MS was recorded on a VG 70-250S GC/MS spectrometer. NMR spectra were recorded a VARIAN UNITY INOVA $500 \mathrm{FT}$-NMR at $500 \mathrm{MHz}$ for ${ }^{1} \mathrm{H}$ and $125 \mathrm{MHz}$ for ${ }^{13} \mathrm{C}$, respectively, in $\mathrm{CDCl}_{3}$ using TMS as an internal standard. Silica gel (Merck, 230-400 mesh) was used for column chromatography. TLC spots ( $\mathrm{Si}$ gel $60 \mathrm{~F}_{254}$, $0.2 \mathrm{~mm}$, Merck) were detected with an $\mathrm{UV}_{254}$ lamp and by $20 \% \mathrm{H}_{2} \mathrm{SO}_{4}$ followed by heating at $120^{\circ} \mathrm{C}$ for $5 \mathrm{~min}$. All solvents used were either freshly distilled or of analytical grade.

Animal Material The gorgonian coral Junceella fragilis was collected by hand using scuba gear off the southern Taiwan coast on Dec. 12, 2002, at a depth of $-10 \mathrm{~m}$. Taxonomic identification was provided by Dr. Tung-Yung Fan from the National Museum of Marine Biology and Aquarium (NMMBA), R.O.C. The living reference specimen was deposited in the NMMBA (TWGC-003). This organism was identified from descriptions. ${ }^{1-3)}$

Extraction and Isolation The organism $(780 \mathrm{~g})$ was collected and freeze-dried. The freeze-dried material $(557 \mathrm{~g})$ was minced and extracted with EtOAc $(5 \times 500 \mathrm{ml})$ for $120 \mathrm{~h}$ at $25^{\circ} \mathrm{C}$. The organic extract $(11.1 \mathrm{~g})$ was separated by silica gel column chromatography using $n$-hexane and $n$-hexane-EtOAc mixtures of increasing polarity. Briarane $\mathbf{2}$ was eluted with $n$-hexane-EtOAc $(5: 2)$ and 1 with $n$-hexane-EtOAc $(1: 1)$.

Junceellolide I (1): White powder $(7.8 \mathrm{mg}) ; \mathrm{mp} 210-212^{\circ} \mathrm{C} ;[\alpha]_{\mathrm{D}}^{25}-77^{\circ}$ $\left(c=0.7, \mathrm{CHCl}_{3}\right)$; IR (neat) $\mathrm{cm}^{-1} 3352,1775,1736 ;{ }^{1} \mathrm{H}-$ and ${ }^{13} \mathrm{C}-\mathrm{NMR}$ data, see Table 1; FAB-MS $m / z: 451,433,391,373,349,331,313$, 295. HR-FABMS: $m / z 451.2332$ (Calcd for $\mathrm{C}_{24} \mathrm{H}_{36} \mathrm{O}_{9}+\mathrm{H}-\mathrm{H}_{2} \mathrm{O}, 451.2333$ ).

$(1 R, 2 R, 5 Z, 7 R, 8 S, 9 R, 10 R, 12 R, 14 R, 17 S)$-2,14-diacetoxy-8,17-epoxy-9,12dihydroxybriara-5,11(20)-dien-19-one (2): Colorless oil $(1.0 \mathrm{mg}) ;[\alpha]_{\mathrm{D}}^{25}$ $+113^{\circ}\left(c=0.1, \mathrm{CHCl}_{3}\right)\left(\right.$ lit. $\left.^{14)}[\alpha]_{\mathrm{D}}+115.1^{\circ}(c=0.08)\right) ;{ }^{1} \mathrm{H}-\mathrm{NMR}(500 \mathrm{MHz}$ $\left.\mathrm{CDCl}_{3}\right) \delta 5.53(1 \mathrm{H}, \mathrm{d}, J=9.0 \mathrm{~Hz}), 5.34(1 \mathrm{H}, \mathrm{d}, J=9.0 \mathrm{~Hz}), 5.31(1 \mathrm{H}, \mathrm{s}), 5.14$ $(1 \mathrm{H}, \mathrm{d}, J=7.0 \mathrm{~Hz}), 5.04(1 \mathrm{H}, \mathrm{s}), 4.77(1 \mathrm{H}, \mathrm{br} \mathrm{s}), 4.35(1 \mathrm{H}, \mathrm{br} \mathrm{s}), 4.31(1 \mathrm{H}, \mathrm{t}$
$J=7.0 \mathrm{~Hz}), 3.04(1 \mathrm{H}, \mathrm{brs}), 2.65(1 \mathrm{H}, \mathrm{brt}, J=15.5 \mathrm{~Hz}), 2.57(1 \mathrm{H}, \mathrm{brd}$ $J=15.5 \mathrm{~Hz}), 2.18(1 \mathrm{H}, \mathrm{m}), 2.00(3 \mathrm{H}, \mathrm{s}), 1.98(3 \mathrm{H}, \mathrm{s}), 1.96(3 \mathrm{H}, \mathrm{s}), 1.88(1 \mathrm{H}$, $\mathrm{m}), 1.78(1 \mathrm{H}, \mathrm{m}), 1.70(1 \mathrm{H}, \mathrm{m}), 1.53(3 \mathrm{H}, \mathrm{s}), 1.26(3 \mathrm{H}, \mathrm{s}) ;{ }^{13} \mathrm{C}-\mathrm{NMR}$ $\left(125 \mathrm{MHz}, \mathrm{CDCl}_{3}\right) \delta 171.8(\mathrm{~s}), 170.6(\mathrm{~s}), 170.2(\mathrm{~s}), 151.7(\mathrm{~s}), 144.5(\mathrm{~s})$, $119.3(\mathrm{~d}), 110.5(\mathrm{t}), 75.0(\mathrm{~d}), 74.3(\mathrm{~d}), 74.2(\mathrm{~d}), 73.6(\mathrm{~d}), 71.4(\mathrm{~s}), 69.7(\mathrm{~d})$, $62.2(\mathrm{~s}), 47.2(\mathrm{~s}), 44.0(\mathrm{~d}), 36.4(\mathrm{t}), 31.2(\mathrm{t}), 28.5(\mathrm{t}), 26.9(\mathrm{q}), 21.4(\mathrm{q}), 21.1$ (q), 15.0 (q), 10.0 (q). The related physical (optical rotation value) and spectral $\left({ }^{1} \mathrm{H}\right.$ - and ${ }^{13} \mathrm{C}$-NMR) data of $\mathbf{2}$ are in full agreement with those reported previously. ${ }^{14)}$

Acknowledgments This work was supported by the grants from the National Museum of Marine Biology and Aquarium and the National Science Council (Contract no. NSC 92-2323-B-291-001 and 92-2320-B-291001) of the Republic of China awarded to P.-J. Sung. We thank Dr. TungYung Fan, the National Museum of Marine Biology and Aquarium, R.O.C., for his collection and identification of the marine organisms.

\section{References}

1) Bayer F. M., Proc. Biol. Soc. Wash., 94, 902-947 (1981).

2) Chen C.-C., Chang K.-H., Bull. Inst. Zool., Academia Sinica, 30, 149-182 (1991).

3) Bayer F. M., Grasshoff M., Senckenbergiana Biol., 74, $21-45$ (1994).

4) Shin J., Park M., Fenical W., Tetrahedron, 45, 1633-1638 (1989).

5) Sung P.-J., Wu S.-L., Fang H.-J., Chiang M. Y., Wu J.-Y., Fang L.-S., Sheu J.-H., J. Nat. Prod., 63, 1483-1487 (2000).

6) Sung P.-J., Fan T.-Y., Fang L.-S., Wu S.-L., Li J.-J., Chen M.-C., Cheng Y.-M., Wang G.-H., Chem. Pharm. Bull., 51, 1429-1431 (2003).

7) García M., Rodríguez J., Jiménez C., J. Nat. Prod., 62, 257-260 (1999).

8) Sung P.-J., Fan T.-Y., Heterocycles, 60, 1199-1202 (2003).

9) Sung P.-J., Lin M.-R., Chen W.-C., Fang L.-S., Lu C.-K., Sheu J.-H., Bull. Chem. Soc. Jpn., 77, 1229-1230 (2004).

10) Sung P.-J., Gwo H.-H., Fan T.-Y., Li J.-J., Dong J., Han C.-C., Wu S.-L., Fang L.-S., Biochem. Syst. Ecol., 32, 185-196 (2004).

11) Sung P.-J., Sheu J.-H., Xu J.-P., Heterocycles, 57, 535-579 (2002), and related references cited therein.

12) Kokke W. C. M. C., Epstein S., Look S. A., Rau G. H., Fenical W., Djerassi C., J. Biol. Chem., 259, 8168-8173 (1984).

13) Sung P.-J., Fan T.-Y., Chen M.-C., Fang L.-S., Lin M.-R., Chang P.-C., Biochem. Syst. Ecol., 32, 111-113 (2004).

14) Bowden B. F., Coll J. C., König G. M., Aust. J. Chem., 43, 151-159 (1990). 